\title{
'Na morte, o segredo dessa vida": admiração, sociabilidade e celebração entre os fãs de Raul Seixas
}

\author{
ROSANA DA CÂMARA TEIXEIRA \\ Doutora em Antropologia \\ Professora da Unilasalle - RJ \\ rosanadacamara@oi.com.br
}

\begin{abstract}
Resumo Este texto tem por objetivo discutir algumas dimensões simbólicas da idolatria, com base em reflexão sobre a trajetória biográfica e musical do cantor e compositor Raul Seixas. Morto em 1989, aos 44 anos de idade, a despeito da ausência física, a admiração e o interesse por sua obra musical e por sua persona intensificaram-se. Multiplicam-se narrativas, transformadas em quadrinhos, livros, poesias, cordéis, vídeos, ensaios, e em sua homenagem organizam-se tributos, shows e passeatas. Pretende-se discutir de que modo significados atribuídos ao artista e a sua obra propiciam a criação de estratégias de construção da memória inspirando variadas formas de identificação e sociabilidade.
\end{abstract}

Palavras-chave: música; idolatria; sociabilidade; celebração; memória coletiva.

$\mathrm{N}$ ESTE ARTigo PRETENDO REFletir sobre as relações entre música, memória e sociabilidade valendo-me de um caso: a idolatria em torno do cantor e compositor Raul Seixas (1945-1989)2 ${ }^{2}$. Morto aos 44 anos de idade, a despeito da ausência física, a admiração e o interesse por sua obra musical e persona intensificaram-se. Desde então, multiplicam-se narrativas, transformadas em quadrinhos, livros, poesias, cordéis, vídeos, ensaios e em sua homenagem organizam-se tributos, shows e passeatas. Todas essas atividades vêm sendo, ainda, redimensionadas pelo advento da internet, favorecendo outras modalidades de interação e divulgação como as páginas (na Internet), as listas virtuais de debates, além das comunidades no Orkut, que conecta pessoas por meio de "uma rede de amigos confiáveis".

Segundo Roberto Da Matta (1991, p. 151), no Brasil fala-se muito mais dos mortos que da morte, o que implica uma estranha contradição porque "falar dos mortos já é uma forma sutil e disfarçada de negar a morte, fazendo prolongar a memória do morto e dando àquela pessoa que foi viva uma forma de realidade". Serve, assim, de foco para os vivos, concretizando os elos que ligam as pessoas de um grupo ou comunidade. Muito embora deixe um certo cenário, ainda mantém 'um elo potente com os que ficaram'.

Para José Carlos Rodrigues (1992, p. 58-59), certos mortos tornam-se 'superpessoas', algo semelhante ao que em geral se denomina de 'patrimônio' cuja vida privada é pública, cuja vida real é mítica. Assim,

1 Canto para minha morte (Raul Seixas/Paulo Coelho, 1976).

2 Parte das argumentações aqui apresentadas foram discutidas na tese de doutorado "Krighá bandolo! Cuidado aí vem Raul Seixas", com publicação prevista para o segundo semestre de 2008. 
estão a meio caminho entre deuses e mortais: "No momento da morte principia a vitória deles sobre a morte, sua transformação em imortal."

Do mesmo modo que os homens são desiguais em vida, eles também o são na morte. Enquanto alguns passam despercebidos, outros inspiram comoção profunda. Se alguns caem rapidamente no esquecimento, outros tornam-se nomes de ruas, praças, viadutos e entram para a posteridade. Raul Seixas virou nome de viaduto em Salvador, de seis ruas em São Paulo e uma no Rio de Janeiro. Além disso, o enfermeiro Arnaldo Tenório, natural de Arco Verde (PE), construiu com recursos próprios e com a ajuda do fã-clube de sua cidade, uma estátua em tamanho natural. Com 1,75 metro de altura, pesando 400 quilos, foi confeccionada em ferro, cimento, gesso e, desde 1994, está na praça de Dias D'Ávila, cidade próxima a Salvador. Em 1991, foi lançado um selo pelo EBCT e, em 2002, o cantor foi homenageado na Câmara Municipal de São Paulo.

Assim, "certos mortos passam a desempenhar um lugar importante para a referência dos vivos. [...]. E num paradoxo notável, é o próprio fato de não mais existirem o que os torna mais valorizados" (Abreu, 1994, p. 208). A morte promove, pois, o renascimento, a reconstrução e o "indivíduo imortalizado passa a ser inventado e reinterpretado" (Rondelli; Herschmann, 1999, p. 3).

Neste artigo, discuto alguns dos significados atribuídos ao artista e à sua obra, com base em certas estratégias de construção da memória colocadas em prática pelos fãs. Documentos, entrevistas e publicações foram utilizados como fontes de pesquisa do relato etnográfico. Assim, o Raul Rock Club - fã-clube oficial - e a passeata são analisados como lugares de memória (Nora, 1984) que favorecem a criação e articulação de redes de sociabilidade. Do mesmo modo, o colecionamento é pensado como experiência central para a construção dessa relação ídolo-fã confirmando a adesão e a própria identidade de admirador.

$\mathrm{O}$ artista e a sua obra: dom, genialidade, autenticidade e carisma

Entre as mais interessantes perguntas não respondidas de nosso tempo está a que indaga quais características estruturais fazem as criações de uma determinada pessoa sobreviverem ao processo de seleção de uma série de gerações, sendo gradualmente absorvidas no padrão das obras de arte socialmente aceitas, enquanto as de outras pessoas caem no mundo sombrio das obras esquecidas (Elias, 1994, p. 52).

Quando se toma por objeto de reflexão a trajetória ${ }^{3}$ de um artista e a repercussão de sua obra depara-se inevitavelmente com certas questões como o dom, a ge- nialidade, o carisma, a autenticidade. Do ponto de vista antropológico, esses conceitos são centrais na análise como algo atribuído e teorizado e não como qualidades que seriam intrínsecas a um certo indivíduo. Em seu estudo sobre Mozart, Nobert Elias (1994) assinala que, ao se falar no alcance, repercussão e perenidade de uma obra, deve-se estar atento às qualidades reconhecidas pelo público e pela crítica, aos aspectos daquele contexto que a fazem ser considerada singular, original.

Assim posto, o que faz com que Raul Seixas e sua obra sejam vistos como fonte de autenticidade? Segundo seus fãs, mais que um cantor/compositor, ele é também poeta, filósofo, profeta. Um ídolo singular, autêntico, original. Mas o que o distingue? Para muitos, ele é o porta-voz de novas idéias, possibilidades de viver e entender o mundo moderno e sua obra seria, então, uma espécie de 'testamento', por ser portadora de uma mensagem que sugere caminhos, alternativas, posturas idealmente libertadoras para o 'angustiado homem contemporâneo'.

De acordo com Gonçalves (1988), nos contextos culturais modernos, poucas noções parecem tão presentes e difundidas tanto nas conversas cotidianas quanto nos debates acadêmicos quanto a de 'autenticidade', podendo ser aplicada a pessoas ou objetos, referir-se a uma experiência pessoal, um documento histórico, uma obra de arte, ou toda uma cultura. Na perspectiva de Walter Benjamim (1987, p. 14), a autenticidade de uma coisa refere-se a tudo o que ela contém e é originalmente transmissível, desde sua duração material até seu poder de testemunho histórico. A aura de um objeto ou ser humano está, portanto, associada à sua originalidade, ao seu caráter único e a uma relação genuína com o passado. Remete a uma realidade longínqua, mediada pelo mistério.

Benjamim (1987) reserva as noções de singularidade e permanência para designar esses aspectos, em contraste com a reprodutibilidade e a transitoriedade de objetos não-auráticos. Precisamente por serem reproduzíveis e transitórios eles não guardam qualquer ligação genuína com um passado individual ou coletivo. Assim, o autêntico refere-se ao original, e o inautêntico à cópia ou à reprodução. Vale lembrar que a autenticidade, como a expressão de um self definido como uma unidade livre e autônoma em relação a toda e qualquer totalidade cósmica e social, só emerge no contexto em que predominam concepções individualistas do self (Gonçalves, 1988).

Se para alguns fãs a popularidade póstuma de Raul Seixas deve-se ao fato de ter sido um autêntico, para outros, a explicação reside em sua personalidade carismática.

De acordo com Weber (1982, p. 138), pode-se falar em carisma quando há o devotamento justificado 
pelo caráter sagrado ou pela força heróica de uma pessoa e a ordem revelada e criada por ela. Trata-se, enfim, de "uma relação social especificamente extracotidiana e puramente pessoal", respaldada na crença ou no reconhecimento. Legitima-se, portanto, pela devoção afetiva tributada a uma pessoa a qual se acredita ter dotes sobrenaturais, uma excepcionalidade, não em virtude de sua posição instituída ou de sua dignidade tradicional, e somente como qualidades lhe são reconhecidas, ou seja, enquanto seu carisma subsiste ${ }^{4}$.

É interessante notar que no caso de Raul Seixas, ao invés de rotinizar-se com o tempo, perdendo sua capacidade de sedução, seu carisma perdura, mantendo sua obra uma aura, um vigor e uma capacidade de despertar interesse e admiração e, em certos casos, até mesmo arrebatamento, levando alguns a se manifestarem como uma espécie de apóstolos obstinados em propagar sua palavra. O domínio carismático autêntico respalda-se, segundo Weber (1974, p. 287), no reconhecimento à missão pessoal do seu mestre. "Sua lei objetiva" emana concretamente da experiência altamente pessoal, da graça celestial e da força divina do herói, rompendo as normas tradicionais ou racionais. A dedicação que lhe é devotada nasce do entusiasmo, seu caráter extraordinário e inaudito. Resguardadas as devidas proporções, não se pretende aqui dizer que Raul é uma espécie de líder, muito embora exerça fascínio sobre alguns que se afirmam seguidores e o chamam de mestre. O mais importante é que a sua morte precoce parece ter acrescentado algo mais a sua aura, reforçando a convicção na sua excepcionalidade. Se fisicamente não tem mais como provar suas qualidades, simbolicamente continua a fazê-lo, por seus fãs, seu testemunho, e as disputas simbólicas travadas o fazem vivo e presente no imaginário e com capacidade para cooptar novos adeptos, admiradores.

\section{Admiração, sociabilidade e memória}

Se por um lado, a admiração por um ídolo constitui-se na motivação básica do fã, é preciso dizer que ela não assume, necessariamente, o caráter de um fervor religioso. A passagem de uma dimensão a outra não é previsível a priori, devendo ser investigada em cada caso. Afinal, o que liga o fã a seu ídolo? Como se dá essa identificação?

Para fins de análise, é fundamental o afastamento de certas visões do senso comum que entendem a idolatria como admiração cega, coisa da idade, estando normalmente associada à adolescência, impulsos e arroubos da juventude, ou ainda a uma necessidade psicológica, de afirmação do indivíduo, revelando a projeção de desejos e carências, podendo, até mesmo, tornar-se perigosos, assumindo um comportamento de risco (Jenson, 1992).

Nesse sentido, a admiração está sendo pensada como um fenômeno social revelador de processos de construção de subjetividades e formas de sociabilidade características da sociedade contemporânea que explicitam certas concepções sobre indivíduo/sociedade, passado/presente, memória e biografia, biografia e contexto, experiências autênticas/inautênticas. Objetiva-se, pois, compreender como as ações de indivíduos diferentes se influenciam reciprocamente e como práticas sociais definem individualidades e, ao mesmo tempo, grupos homogêneos.

$\mathrm{Na}$ chamada sociedade ocidental moderna, a memória dos indivíduos passa a ser socialmente relevante; experiências, desejos, sofrimentos, triunfos passam a ser enfatizados.

Desnaturalizar a noção de memória como dado psicológico, interior aos indivíduos, constitui, pois tarefa primordial de uma análise de um ponto de vista antropológico. Com vistas à realizá-la, torna-se necessário demonstrar seu caráter simbólico, associando-a às questões relativas ao tempo e ao espaço. Nesse sentido, é importante mencionar os estudos acerca da memória empreendidos por Halbwachs (1990). Contrapondo-se à concepção da memória como experiência interior cuja evocação permitiria acessar experiências passadas, este autor afirma que ela é um fato social, reconstruído como base em dados do presente, do vínculo que os indivíduos mantêm com a família, com a religião, com a nação, ou seja, é na relação com os outros que se aprende a lembrar.

\section{O Raul Rock Club como lugar de memória}

O Raul Rock Club, primeiro fã-clube dedicado ao artista, criado em 1981 por Sylvio Passos, autorizado pelo próprio Raul Seixas, conta hoje com um cadastro de sócios provenientes de todo o Brasil. Entidade cultural sem fins lucrativos 'credenciada e autorizada' a divulgar e preservar 'os estudos iniciados por Raul Seixas', o RRC tem entre seus objetivos e filosofia:

Seguir como o fã-clube mais importante em pesquisa, estudo e propagação da vida e obra de seu protagonista. Idealizado e presidido por Sylvio Passos, especialista em raulseixismo e pioneiro no que diz respeito 
à criação de fã-clube com proposta séria de preservação da memória do artista, transcendendo os moldes convencionais. Dedica-se ao estudo e a divulgação dos trabalhos iniciados por Raul Seixas desde 1981 e tem seu trabalho reconhecido em todo Brasil. O Raul Rock Club/Raul Seixas Oficial Fã-Clube não tem fins lucrativos, trata-se de uma entidade cultural destinada a ajudar e orientar pessoas que possuem interesse em conhecer um pouco mais sobre um dos mais importantes, senão o mais importante, cantor/ compositor do cenário artístico brasileiro.

Vivendo de contribuições dos associados e da venda de produtos, deles depende para viabilizar a confecção de novos materiais e despesas de correio, fotocópias, papelaria, laboratório fotográfico e gráfica. Para fazer parte do fã-clube é necessário: enviar carta ou e-mail com dados pessoais como nome, endereço, duas fotos $3 \times 4$, além de uma contribuição e, em troca, o fã recebe um kit raulseixista que contém:

Carteirinha de sócio personalizada (identidade raulseixista); uma fotografia colorida com autógrafo e dedicatória de Raul Seixas; uma cópia do autógrafo; manifesto n.11 da Sociedade Alternativa; Liber Oz ou Liver LXXVII da Sociedade Alternativa; discografia comentada com títulos e datas de lançamento, Incluindo os Compact Discs; uma biografia e o comunicado oficial sobre sua a morte. Além de documentos, o RRC possui manuscritos, fotos e objetos pessoais de Raul Seixas, constituindo um acervo de cerca de 90 itens cujo acesso direto tem sido realizado através de exposições itinerantes, pois não dispõe de um espaço especialmente reservado para este fim.

Sobre esse conjunto de objetos, acumulado em parte durante a convivência com Raul, Sylvio Passos declara:

Tudo que tenho do e sobre o Raul tem um significado especial. Cada item do meu acervo tem uma história, um lance legal. Desde os objetos pessoais até os recortes de jornais e revistas. Cada um deles tem um pouco da minha vida, da minha certeza que tudo que tenho feito vai ficar para as próximas gerações, que Raulzito não vai ser esquecido. Não me sinto dono deste acervo. Quando Raul me falou que eu era "um escolhido" acredito que ele, entre outras coisas, quis dizer que eu seria o responsável pela preservação da memória dele, que eu seria o Guardião de todo este magnífico acervo. E é assim que me sinto: sou apenas o guardador de tudo isso. Este acervo pertence ao povo brasileiro e eu sou apenas o responsável pela boa conservação dele.

O discurso evidencia de que modo a sua condição de guardião do acervo está atrelada à história da amizade que mantiveram, tendo sido escolhido pelo pró- prio Raul para preservá-lo e disponibilizá-lo a todos aqueles que admirem a obra do cantor. Estão ali reunidos objetos pessoais, peças de vestuário, documentos (carteira de identidade, certidão de nascimento e óbito e também a de sócio do RRC), violão, muitos deles presenteados pelo ídolo.

De acordo com Pomian (1983, p. 53), uma coleção é uma instituição que se refere a

qualquer conjunto de objetos naturais, mantidos fora do circuito das atividades econômicas, sujeitos a uma proteção especial num local fechado preparado para esse fim, e expostos ao olhar do público.

No entanto, há que se atentar para o seguinte paradoxo contido implicitamente na própria definição: se por um lado, as peças da coleção são mantidas temporariamente ou definitivamente fora do circuito das atividades econômicas, por outro lado, são submetidas a uma proteção especial e, desse modo, consideradas objetos preciosos. Isso quer dizer que elas têm um valor de troca, sem terem um valor de uso, sendo adquiridas não para serem usadas, mas expostas ao olhar. E sua exibição é capaz de produzir nos fãs uma experiência corporal, psicológica, suscitando comportamentos variados. Há aqueles que querem tocá-los, entrar em contato, senti-los, como se fossem ainda portadores da energia, identidade do cantor, como se algo dele estivesse incorporado.

Esses objetos lembram aqueles definidos por Baudrillard (1968) como mitológicos e, diferentemente dos funcionais - que existem na atualidade, no indicativo, no imperativo prático, esgotando-se em seu uso, na cotidianidade - , respondem a propósitos de outra ordem: testemunho, lembrança, nostalgia, evasão. Se a sua funcionalidade é minimal, seu significado maximal; refere-se à ancestralidade; à anterioridade e exige autenticidade, obsessão pela certeza de sua origem, sua data, seu autor, sua assinatura. O simples fato de o objeto ter pertencido a alguém célebre ou poderoso confere-lhe valor. Note-se que esta exposição, ao produzir uma troca entre o fã e o ídolo, evoca uma ausência e promete um vínculo, por meio dos objetos, portadores daquela essência fisicamente inatingível. Torna, desse modo, o invisível visível, possibilita ainda o encontro dos fãs, promovendo uma interação, uma troca de sentimentos, visões e comportamentos.

Nos termos de Mauss (1974, p. 54), o que, no presente recebido e trocado, cria uma obrigação é o fato de que a coisa recebida não é inerte. Mesmo abandonada pelo doador, ela ainda é algo dele. Por meio dela, o doador tem uma ascendência sobre o beneficiário... É como se a transmissão do presente fortalecesse os laços entre o doador e o receptor, criando, assim, um vínculo pelas coisas que, em realidade, sugere um vínculo entre almas pois 'a própria coisa tem uma alma, é alma'. Disso segue que presentear alguma coisa a al- 
guém é presentear alguma coisa de si, estabelecendose um sistema de dádivas. Está implícito o princípio da reciprocidade: o dar pressupõe um retribuir, pois aceitar alguma coisa de alguém é aceitar alguma coisa de sua essência espiritual, de sua alma.

Tudo vai-e-vem como se houvesse uma troca constante de uma matéria espiritual compreendendo coisas e homens, entre os clãs e os indivíduos, repartidos entre as categorias, sexos e gerações (Mauss, 1974, p. 59).

Portanto, o fã-clube, além de lugar de sociabilidade e memória que se estabelece em torno da admiração pelo ídolo, é também uma coletividade dedicada ao colecionamento. Pode assim ser pensado como um lugar de memória (Nora, 1984), evocando lembranças de um passado próximo ou distante, a trajetória de um artista evidenciada por fotos, fotos autografadas, certidão de nascimento, atestado de óbito, manuscritos de composições, ingressos de shows, cartazes, entrevistas, vídeos, objetos pessoais, cumprindo, assim, a função de superar a temporalidade cotidiana e situando o amor ao(s) ídolo(s) como atemporal, revelandose um lugar de circulação de dádivas. Num mundo em constante processo de transformação, os lugares de memória segundo Pierre Nora - mistos, híbridos e mutantes - bloqueariam o esquecimento, imortalizando a morte, materializando o imaterial.

Desse modo, ao promover a exibição desses objetos, compartilhando com outros o que foi doado, mantém o princípio da reciprocidade, retribuindo a confiança que lhe foi depositada pelo próprio artista e seus familiares. Assim, para além do desejo de divulgar e preservar a obra e a imagem do artista, os fãs-clubes revelam-se importantes e efetivas redes de sociabilidade propiciando o encontro. Especialmente os grupos virtuais que vêm proliferando na internet, prestam-se exemplarmente a este propósito reunindo pessoas física e socialmente distantes propiciando o estabelecimento de relações de amizade e solidariedade como é o caso da Komuna Raulseixístika, grupo virtual do fã-clube oficial criado por Sylvio Passos em dezembro de 2001.

\section{O fã como colecionador}

Do mesmo modo que o fã-clube abriga e exibe sua coleção, sem dúvida, uma face do fã é a de colecionador, alguém empenhado em possuir objetos que pertenceram, foram produzidos ou simplesmente tocados pelo ídolo; reunindo tudo aquilo que diga respeito ao objeto de sua admiração.

Não se trata aqui de mero impulso cumulativo. $\mathrm{O}$ colecionar parece registrar, confirmar a adesão àque- la personalidade, reconhecendo-a como diferencial e significativa. O colecionamento, prática que concretiza um vínculo, constituindo-se, pois num certo modo de construção dessa identidade. Em alguns casos, está presente a idéia de conhecer mediante os objetos, os rastros deixados por aquele indivíduo. Assim, uma gama variada deles revela-se 'bons para colecionar', tornando-se alvos preferidos: discos, livros, entrevistas, imagens em vídeo, tudo pode ser fascinante para este arqueólogo da própria paixão, para o qual, ter domínio da trajetória do ídolo, ou seja, demonstrar conhecimento detalhado sobre sua vida, curiosidades, hábitos, características, gosto, é muito valorizado. É preciso, pois, estar atento ao modo como são organizadas essas coleções e os sentidos que lhe são atribuídos. O trecho abaixo revela a pluralidade de significados que o ato de colecionar pode assumir:

Colecionar, para mim, é um ato de amor. É um tributo solitário que prestamos ao objeto de nossa admiração. A mania de colecionar me acompanha desde que eu me entendo por gente. Colecionar é totemismo? É! Sei disso, mas Raul Seixas merece... ou melhor, eu mereço me tornar totemista por esta causa. Colecionar é recolher infinitamente os pedacinhos daquilo que admiramos, seja nas bancas ou nas lojas, na inútil tarefa de montar o mosaico daquilo que queremos ter muito próximo. Colecionar é masoquismo: sofro pelos discos que não ouvi, sofro pelos livros que não li, sofro por cada entrevista que houve e não tomei conhecimento, por cada ponto de vista que Raul expressou e não pude compartilhar. Mas coleciono. Não entro no mérito da minha coleção de Raul Seixas ser a maior ou a menor de todas, uma vez que ela, seja como for, jamais me suprirá. Mas em cada item que a compõe, existe uma celebração muito minha, particular, de respeito e gratidão, a uma pessoa que já marcou minha vida. Sem rodeios? Eu amo Raul Seixas! Ide ao mundo e pregai o evangelho... raulseixista, lógico.

'Ato de amor', 'tributo solitário', 'mania', 'totemismo'. São tantos os nomes, mas expressam aqui a tentativa de recolher 'os pedacinhos daquilo que admiramos', uma busca incansável de tudo que se refira ao objeto da afeição. Entretanto, ela também comporta uma dose de sofrimento, já que consiste em tarefa 'inútil', que nunca poderá ser plenamente alcançada: há um certo 'masoquismo' neste empreendimento, pois ele representa um desejo que jamais será completamente satisfeito, haverá sempre a suspeita de algo que escapou ao colecionador, e esta incerteza, ao mesmo tempo que o move, o angustia. Há sempre o sonho, o desejo de se descobrir algum objeto, alguma entrevista que não foi classificada, um novo depoimento, uma composição, uma versão musical perdida. Embora incompleta, uma coleção é sempre o tributo, a celebração individual a alguém a quem se reconhece importância. 
Segundo Baudrillard (1968, p. 100), é também pela falta, pelo inacabado que a coleção se separa da pura acumulação. A falta seria a exigência definida deste ou daquele objeto ausente. Nessa perspectiva, indaga o autor se as coleções são feitas para serem completadas ou, se em realidade, a ausência não desempenha um papel central. Em suas palavras:

É preciso se perguntar se a coleção foi feita para ser completada, e se a ausência não desempenha um papel essencial, positivo, aliás, já que a ausência é aquilo pelo qual o indivíduo adquire objetivamente o controle de si: enquanto a presença do objeto final significaria no fundo a morte do indivíduo, a ausência deste termo lhe permite apenas desempenhar sua própria morte, figurando-a em um objeto, vale dizer, conjurando-a. Esta ausência é vivida como sofrimento, mas é também a ruptura que permite escapar ao arremate da coleção que significaria a elisão definitiva da realidade.

De acordo com Clifford (1994), juntar, possuir, classificar e avaliar, sem dúvida, não se restringem ao Ocidente; mas o que aqui parece peculiar é o fato dessas atividades estarem associadas à acumulação (ao invés da redistribuição) ou à preservação (em vez da decadência natural ou histórica). Pergunta-se, pois, o que está em jogo quando se coleciona? Preservar, trocar, expor, vender ou simplesmente guardar? É possível até que, ao acumularem e organizarem esses objetos, os fãs/colecionadores combinem duas ou mais dessas estratégias.

Para Pomian (1983), sob um certo aspecto, toda coleção é formada por objetos homogêneos: participam no intercâmbio que une o mundo visível e o invisível. Nesse sentido, tratar-se-ia de uma instituição universalmente difundida, exatamente pelo caráter universal dessa oposição. Por definição, o invisível é aquilo que não se pode atingir ou dominar com os meios que normalmente se utilizam na esfera do visível. Pode ser o que está muito longe no espaço, além do horizonte, mas também muito alto ou muito baixo. E também o que está muito longe no tempo: no passado ou no futuro. Além disso, é o que está para lá de qualquer espaço físico, de qualquer extensão, ou num espaço dotado de uma estrutura de fato particular. É ainda o que está situado num tempo sui generis ou fora de qualquer fluxo temporal: na eternidade. Trata-se aqui, naturalmente, apenas de quadros vazios, destinados a serem preenchidos pelas entidades mais diversas: antepassados, deuses, mortos, homens diferentes de nós, acontecimentos, circunstâncias.

É preciso, pois, estar atento ao que cada grupo escolhe como digno de ser colecionado e por quê. No caso de Raul Seixas, o desejo de reunir tudo aquilo que o artista produziu (discos, shows), o que disse (entrevistas, livros), mas, igualmente, o que se falou sobre ele, parece realizar a tarefa de preencher a lacuna entre a morte e a vida, transformando a ausência em presença, ligando o mundo visível e o invisível. No entanto há ainda outro aspecto a assinalar, na coleção - organização mais ou menos complexa de objetos - triunfa um empreendimento apaixonado de posse em que todos os objetos remetem ao indivíduo. No fundo, o milagre da coleção reside no fato de que "colecionamos sempre a nós mesmos" (Baudrillard, 1968, p. 98). Assim, está em jogo a formação de uma certa subjetividade, a constituição de uma autoconsciência. A coleção é feita de uma sucessão de termos, mas seu termo final é a pessoa do colecionador. Outros depoimentos exploram mais especialmente esta atitude do fã e seus possíveis significados. Vale dizer que nem sempre a admiração desencadeia o ato de colecionar, muitos já se dizem colecionadores 'natos':

Como bom virginiano já colecionei de tudo, desde revistas em quadrinhos e carros em miniatura até tampas de garrafa e rótulos de vinho. Atualmente coleciono apenas máquinas fotográficas antigas e livros. E mantenho minha velha coleção de selos. Do Raul tenho praticamente tudo. Tudo o que foi vendido no mercado eu tenho. E ainda vários vídeos que o Sylvio me passou e alguns ainda inéditos. Também tenho muita coisa de Jerry Lee Lewis e Elvis, entre vídeos e CDS piratas. Como colecionador, sinto falta de um objeto do próprio Raul. Mas não um cuspe ou um sapato de bebê... O que eu gostaria de ter é algo como um quadro ou um manuscrito original para enquadrar e deixar na parede... Um violão ou guitarra... Ou um casaco de couro... Se alguém tivesse algo original mesmo, que me agradasse, eu pagaria muito bem.

Incansável, o fã busca um objeto 'original', 'do próprio Raul', que guarde seu caráter especial, seja portador de um mana, uma qualidade, um poder que o distingue. Assim, se o colecionador é movido pela paixão, este sentimento é regrado, não se busca uma simples acumulação, mas juntar objetos considerados significativos, acalentando-se mesmo o ideal de obter algo raro, não em seu valor monetário, mas por ser único. Os objetos, assim, são mais do que simplesmente objetos, possuem uma eficácia mágica (Mauss, 1974). É como se ficassem encantados, e através deles fosse possível promover um encontro, fisicamente impossível. Dois casos se destacam, ainda, pelo inusitado dos objetos adquiridos. Um fã conseguiu a grama do cemitério onde está a sepultura de Raul Seixas e a plantou em seu jardim. Segundo narrou, a grama cresceu, se espalhou e a notícia também, atraindo muitos fãs que procuravam o local com o intuito de tocá-la. Outra história curiosa é do fã que pediu a um amigo que na sua passagem por Salvador, visitasse o cemitério em que Raul está sepultado e recolhesse um pouco da areia do local. 
Declarando-se um colecionador compulsivo, estabelece, no entanto, uma diferença crucial: tudo que possui do artista, não pode, em sua percepção, ser classificado como coleção: "Sou um colecionador compulsivo tenho várias coleções, entre as quais eu destaco minha coleção de HQ, minha coleção de cards e a de cactus. Meu material de Raul não é coleção, é sentimento puro."

Uma outra possibilidade é a de que o próprio sentido atribuído à coleção se modifique ao longo do tempo, como se a obsessão inicial de obter tudo, zelando esse acervo de qualquer eventual risco de perda ou destruição, fosse paulatinamente substituída por um desejo de compartilhar; a obstinação em recolher permanece, mas pode ocorrer um certo desapego.

A importância de tudo que juntei sobre o Raul? Mudou com o passar dos anos. No início era aquela doideira, tinha que juntar tudo, não podia ver nada que tinha que pegar. Aliás até hoje ainda é assim. Só que com a internet, o material se tornou mais fácil, amplamente difundindo, especialmente após a morte. Enquanto ele era vivo e maldito, tudo era uma raridade, uma reportagem, uma aparição na TV. Sabia que esses vídeos todos que hoje temos não existiam enquanto ele era vivo? Eu por exemplo, tinha pouquíssima coisa, "cowboy fora da lei", algumas apresentações em programas populares e só. Cheguei ao cúmulo de gravar (diversas vezes) em fita k7, aparições do Raul na TV - Festival de Iacanga, Globo Repórter, pois naquela época nem o vídeo era muito comum... Mas com o tempo houve um desapego... Creio que esteja relacionado ao nascimento do primeiro filho, quando você vê aquele ser, que é a coisa que mais ama na vida, com um disco do Raul, assim... na boca, em outros tempos eu teria um chilique monumental, depois dos filhos... Você apenas ri. E também acho que comecei a sacar melhor as coisas, ainda junto tudo o que posso, mas não tenho mais aquela adoração toda por este material, depois que você é assaltado algumas vezes, perde alguém querido, ou pior, perde toda a memória do seu computador... Essas coisas passam a ser menores. E fiquei feliz com essa conclusão, porque senti que aprendi um pouco mais com o Raulzito, afinal ele não pregou a generosidade, em todos os seus atos? Então, você passa para o time daqueles que "entenderam o recado", o que é muito reconfortante... Digamos que durante um tempo, aquele material era TUDO para mim, e continua ao meu lado, acrescido ainda de tanta coisa que consegui através de vocês pesquisadores. Mas o que posso concluir é que se hoje eu perdesse tudo isso que tenho nas minhas gavetas, estantes, prateleiras, tudo bem, ia ficar muito triste, mas não seria o mesmo fim do mundo de uns... doze anos atrás... Mais duro seria se eu perdesse essa generosidade, que eu demorei tanto a descobrir, de saber que um ser humano, uma amizade, vale muito mais que qualquer papel ou disco...

Se o impulso para juntar existe, o valor atribuído à coleção não é o mesmo. Esse desapego é explicado não apenas pela abundância de material hoje disponível, ao contrário do passado, mas também porque as experiências de vida - o nascimento do primeiro filho, a perda de pessoas queridas - alteram o sentido conferido ao acervo. Note-se que aqui, essa mudança é muito especialmente situada como fruto de um aprendizado que a vida e a obra do Raul propiciam, nesse caso, o da generosidade, uma de suas qualidades. Assim procedendo, o fã acredita que 'entendeu o recado': as relações humanas são mais valiosas que qualquer objeto. $\mathrm{Na}$ fala que se segue, a coleção de discos, obtida com sacrifício, ficou na casa da mãe, aos seus cuidados, e o seu sentido é escutá-los juntos num ritual que se repete nas poucas vezes que retorna à cidade natal:

Minha modesta coleção de LPs do Raul que consegui ao longo de alguns anos até hoje é cuidadosamente guardada pela minha mãe, numa cidadezinha de 4 mil habitantes, no interior de Santa Catarina. Nunca tive coragem de tirá-los de lá e trazê-los para Joinville... Cada disco tem uma história especial para mim e quase todos um ponto comum: foram muito difíceis de conseguir (por falta de dinheiro mesmo). Eu ia na loja de discos, encontrava o LP e escondia entre os discos evangélicos e voltava quando descolava dinheiro para comprá-lo... Ô dureza.... Hoje, nas poucas vezes que vou à casa da minha mãe, ela faz questão de me mostrar todos os discos, da mesma forma que eu os deixei quando saí de casa, e pede para eu colocar "A hora do trem passar" e ouvir com ela. Esse "ritual" se repete sempre. Os discos hoje pertencem a ela. Quero um dia chegar com meus filhos e ouvir Raul com a "vovó"... $\mathrm{O}$ dia que ela não estiver mais vivendo nesse mundo, não sei o que farei com os discos... Eles já não terão o mesmo valor para mim, como hoje já não têm o mesmo valor de quando eu os adquiri...

Como se pode perceber, o ato de colecionar assume vários significados. Do 'tributo solitário' à busca incansável e obstinada de alguém que se lança num propósito que jamais poderá ser plenamente satisfeito: haverá sempre a suspeita de algo perdido. E se essa incerteza o move, também o atormenta. Além disso, constrói e mantém laços de afeto. Alguns procuram indistintamente tudo que se refira ao ídolo, outros demonstram preferência por imagens, reportagens ou ainda objetos inusitados como a areia e a grama do cemitério em que o artista está enterrado, por exemplo. Há aqueles ainda cujo sonho é encontrar algo raro, original, único que tenha pertencido ao Raul. De qualquer modo, o que se acumulou parece distinguirse de tudo mais, é 'sentimento puro'. Guardar, cultu- 
ar, compartilhar, trocar, e até desfazer-se: a admiração determina a forma de se comportar em relação aos mesmos, a qual pode transformar-se com o tempo. Implica, ainda, uma reflexão sobre o significado dos objetos e através deles sobre si e suas vidas.

\section{A passeata como evocação e celebração}

Todos os anos, desde 1989, no dia 21 de agosto, os fãs do cantor e compositor Raul Seixas lembram sua morte. Eventos são realizados para homenagear aquele que é considerado 'o pai do rock nacional'. Deve-se dizer, no entanto, que tais celebrações não se restringem a esta data. Ao longo do ano, especialmente na cidade de São Paulo, onde o artista viveu nos últimos anos de vida, ocorrem encontros promovidos por fãs e fãs-clubes com destaque para o Raul Rock Club (RRC).

No entanto, o aniversário de morte é um momento privilegiado no qual emergem representações acerca do homem, da obra e aquelas que os amigos e admiradores têm de si mesmos. Afinal qual o sentido em se evocar o morto? O que está em destaque nestas ocasiões? Regina Abreu (1994, p.206) em sua análise acerca das comemorações envolvendo os escritores Euclides da Cunha e Clarice Lispector indaga: "por que lembrar alguém exatamente na passagem do aniversário de sua morte? O que esse fenômeno tem de singular?"

Do mesmo modo que o RRC, a passeata pode ser pensada como 'lugar de memória'. Os 'lugares de memória' seriam tanto lugares materiais, a exemplo de museus e arquivos, quanto lugares pouco palpáveis ou imateriais, como aniversários, elogios fúnebres, rituais, comemorações.

Pierre Nora (1984) propõe a exploração de todos os sentidos da categoria 'lugares', dos mais materiais e concretos - como os monumentos aos mortos e os arquivos nacionais - aos mais abstratos e intelectualmente construídos, como a noção de linhagem, de geração, região e de 'homem memória'.

Nessa perspectiva, o aniversário de morte constitui um momento privilegiado no qual emergem representações acerca do homem, da obra e aquelas que os amigos e admiradores têm de si mesmos. De acordo com Abreu (1994, p. 208), "lembrar do morto é falar sobre ele, relatar seus feitos, discorrer sobre suas alegrias, suas angústias, seus amores, suas aquisições, suas insatisfações, suas frustrações, suas obras inacabadas, enfim, é evocar sua passagem pela vida na terra".

Assim como os euclidianos - admiradores do escritor Euclides da Cunha - analisados pela autora, os raulseixistas - como se auto-representam certos fãs de Raul Seixas - se vêem como diferenciados exatamente porque entendem ter uma espécie de missão: propagar sua obra, entendida como mensagem, legado a ser preservado e, sobretudo, continuado.

Ao evocar, lembrar, continuar, os raulseixistas se convertem em produtores da memória social. A passeata $^{5}$, nessa perspectiva, pode ser definida como uma tradição inventada (Hobsbawm, 1984) pelos fãs. Evento híbrido, conjuga aspectos formais - pressupõe certo planejamento, possui data, local, horário e um trajeto definidos (dia 21/08 com concentração prevista para as 16 horas no Teatro Municipal e saída às 18 horas atravessando o Vale do Anhangabaú até a Praça da Sé, culminância do evento onde se observa o congraçamento entre os fãs) - e informais: trata-se de uma situação dominada pela brincadeira, diversão, licença, clima de festa e confraternização, observandose a suspensão temporária das regras.

Organizado por associações voluntárias, tem-se a possibilidade de reencontrar amigos, conhecer pessoas. A celebração ao ídolo aglutina, temporariamente, percursos sociais muito diferenciados. Chama a atenção a heterogeneidade, homens, mulheres, adolescentes, crianças levadas pelos pais, pessoas com mochilas, indicam terem vindo de outras cidades. Tendo em vista que há espaço para todos os personagens, categorias e grupos, engendra-se um campo social cosmopolita, polissêmico, por excelência: seu mecanismo básico é o da inversão, uma vez que junta categorias e papéis normalmente separados, idades, posições sociais não são determinantes. Pelo menos essa é a sua promessa. Na passeata, configura-se um campo da licença, do joking, produzindo-se uma espécie de momento communitas, em que predomina uma certa comunhão em torno da homenagem a Raul Seixas: ele é a razão da festa e por isso, sua imagem está presente em camisas, tatuagens, faixas e bandanas.

Como numa espécie de culto profano, os fãs, muitos deles considerando-se fiéis seguidores, celebram, rememoram e reverenciam Raul Seixas entoando suas canções, vestidos e travestidos à sua imagem e semelhança, lançando vivas à Sociedade Alternativa' ${ }^{6}$ Re-

5 Em 16 de abril de 2007 foi aprovada a Lei n. 14.373, do vereador Carlos Giannazi (PSOL): Art. 1 - Institui o "Dia Para Sempre Raulzito", a ser comemorado anualmente na data de 21 de agosto, dia da morte do cantor e compositor Raul Seixas. Art. $2^{\circ}$ - O vento passará a constar no Calendário Oficial de eventos do município de São Paulo.

6 Para compreender as apropriações da obra de Raul Seixas é fundamental conhecer os significados atribuídos à Sociedade Alternativa, criada pelo artista e pelo escritor Paulo Coelho em 1973. Muitos admiradores portam seu símbolo em tatuagens, pingentes, estampados em camisas (Teixeira, 2004). 
forçando os laços com o ídolo, convertem aquele fisicamente ausente numa presença, mediante um manifesto criado por e para os fãs que ali vivem um momento de catarse coletiva, afirmando-se como coletividade frouxa e temporariamente articulada em nome da admiração, da devoção e da saudade. Nessa ocasião, diferentemente das disputas simbólicas observadas entre raulseixistas e raulmaníacos ${ }^{7}$ na comunidade virtual, todos parecem submetidos a uma identidade comum, abrangente e encompassadora: a de 'fãs do Maluco Beleza'.

A passeata, ritual que se repete todos os anos é a culminância de um período ritual que se inicia em 28 de junho (aniversário do cantor) quando se intensificam homenagens, tributos, com shows de covers, exposições, lançamento de livros. Do mesmo modo que o observado entre os euclidianos, que ao se dirigirem para a cidade anualmente, ao participarem das mesmas atividades que se repetem todos os anos, parecem haver encontrado um referencial seguro, um ponto fixo e extraordinário que contrasta com o cotidiano de suas vidas, a passeata propicia encontros e reencontros, criando para muitos fãs laços de continuidade.

\section{Conclusão}

De acordo com Dumont (1985), as sociedades modernas seriam marcadas pelos ideais de igualdade $\mathrm{e}$ de liberdade, observando-se a valorização do íntimo, do privado, da afetividade e da emoção relacionadas ao indivíduo como valor cultural fundamental. É à medida mesmo que o indivíduo se torna a unidade básica significativa que suas trajetórias assumem relevância como elemento constituidor da sociedade. Assim, experiências pessoais, amores, desejos, sofrimentos são enfatizados. É importante registrar que o espaço das metrópoles, marcado pela impessoalidade, pelo anonimato e pela heterogeneidade de modos de vida aparece como o locus privilegiado da idéia de fragmentação. Para alguns autores, esta idéia - um dos indícios da modernidade - diz respeito à multiplicidade de referências, seja em termos de grupos ou de atitudes. Se as ideologias individualistas, por um lado, marcam o advento do indivíduo sujeito, por outro, expressam a fragmentação de domínios que sucede a uma ordem tradicional hipoteticamente mais integrada.

Portanto, se a metrópole expõe os indivíduos a situações múltiplas, contraditórias ou fragmentadoras; por outro lado há que se pensar sobre as experiências que dão um sentido de continuidade, conferindo significado às trajetórias individuais, permitindo reestrutu- rar seus esquemas de percepção. Até que ponto a inserção num fã-clube e a admiração por um ídolo implicam uma adesão significativa para demarcação de fronteiras e elaboração da identidade dos indivíduos?

O estudo mais aprofundado das redes de sociabilidade criadas em torno da memória de Raul Seixas contribui para este campo de reflexões. Afinal, como explicar o grande número de fãs-clubes, de covers - sósias -, as homenagens póstumas, a publicação de livros e a realização de passeatas? A morte/ ausência parece ter desencadeado narrativas, gerando uma obsessão pelos objetos, pela acumulação. O desejo de reunir tudo aquilo que o artista produziu (discos, shows), o que disse (entrevistas, livros), mas, igualmente, o que se falou sobre ele, parece cumprir a tarefa de preencher a lacuna entre a morte e a vida, transformando a ausência em presença, ligando o mundo visível e o invisível. Assim, está em jogo a formação de uma certa subjetividade, a constituição de uma autoconsciência.

Rememorar o processo pelo qual se tornou fã de Raul Seixas, a criação/ligação com o fã-clube, a organização da coleção, a participação nas passeatas significa lembrar de quem se é e, ao mesmo tempo, se pensar como pertencente a uma certa coletividade.

Isso significa dizer que a idéia de uma memória individual passa a ser pensada como entrecruzamento de memórias coletivas. A lembrança depende, de referências temporais e espaciais, categorias construídas culturalmente, sendo uma experiência sempre mediatizada por representações coletivas, narrativas, imagens. Uma vez que o passado não se encontra em "alguma galeria subterrânea de nosso pensamento, inteiro em suas imagens completas dentro de nossa memória" (Halbwachs, 1990, p. 77), é na sociedade que devem ser procuradas as indicações necessárias a sua reconstrução.

Deve-se enfatizar, ainda uma vez que, do ponto de vista antropológico, a referência é o presente, ou seja, toda memória é uma reconstrução com base na visão de mundo atual do grupo. Nesse processo, o que está em jogo não é simplesmente a legitimação de uma posição, mas a fabricação de uma identidade por uma certa representação do passado que afeta a nossa posição atual.

A ênfase recai numa continuidade entre passado e presente, pois o passado, como sistema simbólico, não é anterior ao presente. O que existem, na verdade, são representações coletivas sobre o mesmo: experiências que as pessoas chamam de passado/memória para pensar e reorganizar o presente (Velho, 1994). Ao fazê-lo, por meio de certas linguagens, os indivíduos redescobrem a sua posição social e elaboram uma perspectiva futura. 


\section{Referências}

ABREU, R. Entre a nação e a alma: quando os mortos são comemorados. Rio de Janeiro: Estudos Históricos, v.7, 1994, p. 205-230. BAUDRILLARD, J. O sistema não funcional ou o discurso subjetivo. In: O sistema dos objetos. São Paulo: Perspectiva, 1968, p. 81-116.

BENJAMIN, W. A obra de arte na época de sua reprodutibilidade técnica. In: Obras escolhidas. Magia e técnica, arte e política. Ensaios de Literatura e História da Cultura. São Paulo: Brasiliense, 1987, p. 165-196.

BOURDIEU, P. A ilusão biográfica. In: FERREIRA, M. M.; AMADO, J. Usos e abusos da História Oral. Rio de Janeiro: FGV, 1996, p. 183-191.

CLIFFORD, J. Colecionando arte e cultura. Revista do Patrimônio, n. 23, 1994, p. 69-89.

DA MATTA, R. A morte nas sociedades relacionais: reflexões a partir do caso brasileiro. In: A casa e a rua. Rio de Janeiro: Guanabara Koogan, 1991, p. 143-170.

- Carnavais, malandros e heróis. Para uma sociologia do dilema brasileiro. Rio de Janeiro: Zahar Editores, 1983.

DUMONT, L. O individualismo. Uma perspectiva antropológica da ideologia moderna. Rio de Janeiro: Rocco, 1985. ELIAS, N. Mozart. Sociologia de um gênio. Rio de Janeiro: Jorge Zahar Editor, 1994.

GONÇALVES, J. R. Autenticidade, memória e ideologias nacionais: o problema dos patrimônios culturais. Estudos Históricos, v. 1, n. 2, Rio de Janeiro: FGV, 1988, p. 264-275.

HALBWACHS, M. A memória coletiva. São Paulo: Vértice, 1990.

HOBSBAWM, E. A invenção das tradições. São Paulo: Paz e Terra. 1984.

JENSON, J. Fandom as pathology: the consequences of characterization. In: LEWIS, L. The adoring audience: fan culture and popular media. Routledge, 1992, p. 9-21.

MAUSS, M. Ensaio sobre a dádiva. Forma e razão da troca nas sociedades arcaicas. In: Sociologia e Antropologia. São Paulo: EDUSP, 1974, p. 37-178.

NORA, P. Les lieux de mémoire I - La république. Paris: Gallimard, 1984.

POMIAN, K. Coleção. Enciclopédia Einaudi, 1983.

RONDELLI, E.; HERSCHMANN, M. Os media e a construção do biográfico - a morte em cena. XXIII Encontro Anual da Anpocs, GT Biografia e memória social, 1999. RODRIGUES, J. C. Quando a morte é festa. In: Antropologia do poder. Rio de Janeiro: Terra Nova, 1992, p. 55-75. TEIXEIRA, R. da C. A gente ainda nem começou: idolatria e culto entre os fãs de Raul Seixas. PontoUrbe Revista do Núcleo de Antropologia Urbana da USP, ano 1, julho, 2007. Disponível em: http://www.n-a-u.org/Teixeira.html.

. Krig-ha Bandolo! Cuidado, aí vem Raul Seixas. Tese

(Doutorado em Antropologia Cultural)- Programa de PósGraduação em Sociologia e Antropologia da Universidade Federal do Rio de Janeiro, 2004.

Os perigos da paixão: visitando jovens torcidas cariocas. São Paulo: Annablume, 2004.

VELHO, G. Projeto e metamorfose: antropologia das sociedades complexas. Rio de Janeiro: Jorge Zahar Editor, 1994.

WEBER, M. A sociologia da autoridade carismática. In: GERTH, H. H.; MILLS, W. (Orgs.). Ensaios de sociologia. Rio de Janeiro: Jorge Zahar Editor, 1974, p. 283-289.

- Os três tipos de dominação legítima. In: COHN, G. (Org.). Coleção Grandes Cientistas Sociais. São Paulo: Ática, 1982, p.128-141.

\section{'The Secret of Life in Death': Admiration, Sociability and Celebration among Raul Seixas' Fans}

\section{Abstract}

The goal of this paper is to discuss the symbolic dimensions of idolatry, from the reflection on the biographical and musical career of singer and songwriter Raul Seixas. He died in 1989 when he was 44 years old, and, despite his physical absence, the admiration for his musical work and for his persona was intensified. Narratives were transformed into books, comics, poems, twines, and videos. Essays were written and, in order to pay homage to him, concerts and walks are still organized. This text intends to discuss how meanings attributed to the artist and his work lead to the creation of memory construction strategies inspiring varied forms of identification and sociability.

Key words: Music; idolatry; sociability; celebration; memory. 